\title{
Organizational Culture and its Influence on Sustainable Construction among Johor Malaysian Construction Industries
}

\author{
N.H. Doni ${ }^{\mathrm{a}}$, and A.Q. Adeleke $\mathrm{a}^{\mathrm{a}}$, A.I. Ismail ${ }^{\mathrm{b}}$ \\ ahashimadoni97@gmail.com, aadekunle@ump.edu.my, biyanda@uof.ac.ae \\ ${ }^{a}$ Faculty of Industrial Management, Universiti Malaysia Pahang, Lebuhraya Tun Razak, 26300 Gambang, Pahang, Malaysia \\ ${ }^{b}$ College of Business Administration, University of Fujairah, UAE
}

\begin{abstract}
This research studies investigate the influence of organizational culture on sustainable construction among Johor Malaysian construction industries. As there is an opinion that supported the need to integrate a culture that reinforces devotion towards sustainability in an organization to ensure a successful sustainability adoption in project' activities. Therefore, in response to this perception, the objective of this study is to investigate the relationship between clan culture and market culture on sustainable construction. To achieve this, quantitative research was conducted with a corresponding stratified random sampling used to choose the sampled construction companies. Mainly those that are registered under the Construction Industry Development Board (CIDB) Malaysian operating in Johor. A total of 107 valid and completed questionnaires were returned. The validity, as well as the reliability of the item in this research, were assessed using the PLS-Sem measurement model and it shows the results are reliable. The two hypotheses were tested and the result shows that the clan culture variable has a significant positive relationship on sustainable construction $(\beta=0.241, \mathrm{t}=4.431, \mathrm{p}=0.000)$ and market culture also show a significant positive relationship on sustainable construction $(\beta=0.820, \mathrm{t}=22.469, \mathrm{p}=0.000)$ as an organizational culture with dynamism, which is represented by clan culture and market culture are conclude to be influential in sustainability, and also play a critical role in a society in the context of sustainability and corporate citizenship. Implications for practice and future research were also discussed.
\end{abstract}

Keywords: Organizational culture, clan culture, market culture, sustainable construction industries, Malaysia.

\section{Introduction}

Malaysian construction industries play an important role in the build-up the lives of the citizens which is also very important to the development of the country and nation. Furthermore, as know that construction companies in Malaysia have also increased the employment rate in the economy (Khan et al., 2014). Malaysian is vigorously working toward achieving high-income status by 2020 . This encompasses the serious transformation of the economic structure. With this statement, business needs to adopt organizational culture with increasing insight, and accomplishment to balance the internal and external dynamism, thus, giving general patterns of behavior to the organizational culture within the organization (Acar \& Pinar, 2014). Sustainable development is the framework for developing our perception of sustainable construction concepts, which have evolved as a new element for constructing a favorable building design that satisfies the existing needs of humans without sacrificing them for future generation's capacity (Ofori 2001). The sustainable building basically encompasses the triple bottom line (TBL) of natural, social and economic characteristics characterized in the slogan of sustainable growth (Tan, Shen, \& Yaoo, 2011). Sustainable construction has also been asserted to radically fix the dynamic issues of construction and the ecosystem in an attempt to re-establish the connection between natural and environmental concerns (Du Plessis 2002). Given the scope and relevance of the construction industry to many nations' industrial prosperity (studies such as Giang \& Pheng 2011; Wang 2014 showed that construction growth has been an infrastructure investment of part of Africa, Asia and the Pacific region's economic growth, and its enormous relation to environmental harm, recommendations have been provided to recognize the adoption of sustainable construction as most critical requirements for evaluating the overall output of the construction industry (Murray $\&$ Cotgrave 2007). Sustainable construction would increase the success of the construction industry and make a major contribution to environmental preservation. 
Culture is the determinant of the stance and attitude of people and organizations (Wang \& AbdulRahman, 2010). All behavior such as the way of driving, studying, working in a team, table manners, greetings, and walking are fragments of culture. Cultures grew over time and being transferred from generation to generation. It is important to understand the culture of an organization I order to observe the situation in the organization, to operate it and to mend it accordingly.

Additionally, organizational culture can be defined as the shared values, beliefs, and practices existing in the organization (Acar \& Pinar, 2014). It is recognized by many scholars that organizational performance and long-term effectiveness is affected by organizational culture (Chung et al., 2020) Studies have shown that things that distinguished successful businesses from others are their organizational culture (Agrawal, 2017).

Moreover, examining organizational culture on sustainable construction, need to be done within the context of the Malaysian Construction Industry (MCI). However, it is been set up that the construction project delivery could enhance with government support (Qiang et al. 2015; Azman and Adeleke, 2018). Furthermore, thought or consideration also may enlarge the perception by providing empirical and theoretical evidence on how it affects the relationship that keeps going between organizational culture and sustainable construction in the surrounding of Malaysian large construction sector. Consequently, sustainable construction has created a lot of interest within the Malaysian construction industry (MCI) for a long period, as the country advanced to become one of the first countries globally to demonstrate significant worries about the environmental effects of construction by enacting the Environment Quality Act back in 1974. (Hamid et al. 2011). Given this, the sector has been troubled by many unsustainable activities (Abdul-Rahmanet al. 2006; Goh \& Abdul-Rahman 2013; Mehr \& Omran 2013; Adeleke et al., 2020). In addition, despite many prominent studies on sustainable construction (e.g. Du Plessis 2002; Abidin 2009; Shen et al. 2010; Liu et al. 2011), relatively few consideration has been devoted to the impacts of organizational cultural factors on sustainable construction. Hence, this study is geared towards bridging this gap by investigating the influence of organizational culture on sustainable construction in the Malaysian construction companies.

\section{Literature Review}

\subsection{Overview of the Malaysian Construction Industry}

The construction sector in Malaysia is cover in the aspect of design, planning, conservation, demolition and repairing the countless type of buildings and all types of mechanical and civil engineering works and other fieldwork involved (Ofori, 1990). The construction consists of repairing a building, building a new structure, renovating old structures and maintenance or other engineered structures such as utility systems and highways (Bamgbade et al., 2019; Ismayana \& Adeleke, 2020; Wang \& Abdul Rahman, 2010). Furthermore, construction is just not limited to the building but also divided into several activities such as landscaping, electrical supply, plastering, paving, painting, and telecommunications.

Moreover, the construction industry plays a huge role in the national welfare of a country through the development of housing and office buildings, education and health centers, industrial plants, transport infrastructure and the restoration of the nation's infrastructure as well as other public facilities (Kanimoli et al., 2020; Taofeeq et al., 2020). Meanwhile, the other sides of the economic construction industry show that it is different from other industrial products because it is considered unique and a very important asset. In terms of the sale and purchase of the building and also another item it is mostly different.

Clan (cooperative) culture is shaped between the dimensions of an organization that flexibility, more focus and dynamism. The clan culture possesses high affiliation and concern with teamwork and participation (Quin and Spreitzer, 1991). Organizational commitment is a culture type that has to seem in an organization, acting as a family has a social feature as trust, solidarity, and unity (Berrio, 2003, Cameron and Quin, 1999; Erdem, 2007; Panda et al., 2020).

Furthermore, the clan culture is filled with common goals and shared values, an emphasis on empowerment and employee involvement, and an atmosphere of mutual help. A leader is a mentor and teamwork is emphasized. It focuses more on maintaining its stability, loyalty, cohesiveness, and participation. Market (competitive) culture occurs at the time of stability and control. This is a rational culture that emphasizes achievement (Quinn and Spreitzer, 1991). Employees in these culture types are success-oriented. They give importance to personal interests rather than organizational goals and emphasis the concepts of performance, planning, and efficiency. Global businesses that have an effective relationship between customers, suppliers, and 
external stakeholders are an example of this organizational culture (Berrio, 2003, Cameron and Quinn,1999; Erdem, 2007).

Next, market culture is also being called a "compete for culture" because of its emphasis on the result. In a simple form, people mainly want to win and accomplish what has been set out to do. Leaders are tough and demanding to achieve the success metric the company has defined and also employees are highly goal-focused. But at the same time rewarding when that hard work pays off with real, measurable value. Finally, an organization with a market culture combines structure with outside or external focus. It values communication and accomplishments, is task-centric, integrates decision making, and has clear goals. These goals, in turn, cultivate competitiveness, resulting in higher short-term productivity (Cameron and Quinn, 1999). This culture is founded on the belief that clear objectives and conditional rewards motivate staff to perform effectively (Cameron and Quinn, 2006).

\subsection{Relationship between Clan Culture and Sustainable Construction}

Specifically, since clan culture type gives weight to cohesiveness, participation, and teamwork. The significance of this culture type is on developing shared understanding and commitment instead of the formalized communication process (Quin, 1988; quin Rohrbaugh, 1983:363-377). Organizational cohesiveness and personal satisfaction are more rated than financial and market share objectives. The fundamental policies focus on developing commitment, human resources, and morale (Desphande et al., 1993; 25-26). Organizational culture with dynamism and as corporate entities represents clan culture to be influential in sustainability and play a critical role in a society in the context of sustainability and corporate citizenship. Preuss, (2008) and Tuan (2012) also mentioned that clan culture is the most appropriate preference for sustainability-oriented organizations, and sustainability can be fully exploited through entrepreneurship as it assists organization's capability. Based on the aforementioned argument, it is therefore, hypothesized that;

Hypothesis 1: There are significant relationship between clan culture and sustainable construction.

\subsection{Relationship between Market Culture and Sustainable Construction}

In an organization with a culture which is more structured and organized, corporate values are clearly defined in attaining the predicted goals or outcomes. Market culture is another acceptable option of culture that is applicable in integrating sustainability in the organization process. This is due to the clear clarification of sustainability practices (Wang \& Abdul-Rahman, 2010). The internal factors as well as external factors, in a construction organization, plays a critical part in adopting sustainability in a project (Omer and Adeleke, 2019; Bamgbade; et al., 2019; Efferin \& Hopper, 2007) as it is the heart of a business. Meaning, of the internal factors of a business, must be strong enough before moving to the external factors (Homburg \& Pflesser, 2013). Adoption of sustainability in construction has quicker progress in clan organizations (Kargas \& Varoutas, 2015) as employees are able to adapt and follows changes accordingly since they are bound by rules, and they are obligated to cooperate once policies on sustainability are embedded in the company's values (Oney-Yazici et al., 2007). Market culture combines structure with the outside or external focus. Its values communication and achievement, it is task-centric, integrates decision making and has a clear goal. These goals, in turn leads to competitiveness, result in higher short-term productivity (Cameron and Quinn, 1999). Lastly, as market culture is known for its rigidity and adherence to rules. Leadership or authorities with power have a vital role in inculcating the awareness and practices of sustainable development in the organization as everyone is bound to follow every rule in the organization (Wang \& Abdul-Rahman, 2010). We therefore, hypothesized that;

Hypothesis 2: Market culture has a positive and significant influence on sustainable construction.

\subsection{Conceptual Framework}

This research is developed with a clearly defined independent and dependent variables by using a specified model. Based on the conceptual framework, the independent variables in this research are a clan culture and market culture and dependent variable is sustainable construction. Specifically, the framework shows the relationship between these variables on order to determine whether there is a significant relationship between the variables or not. 


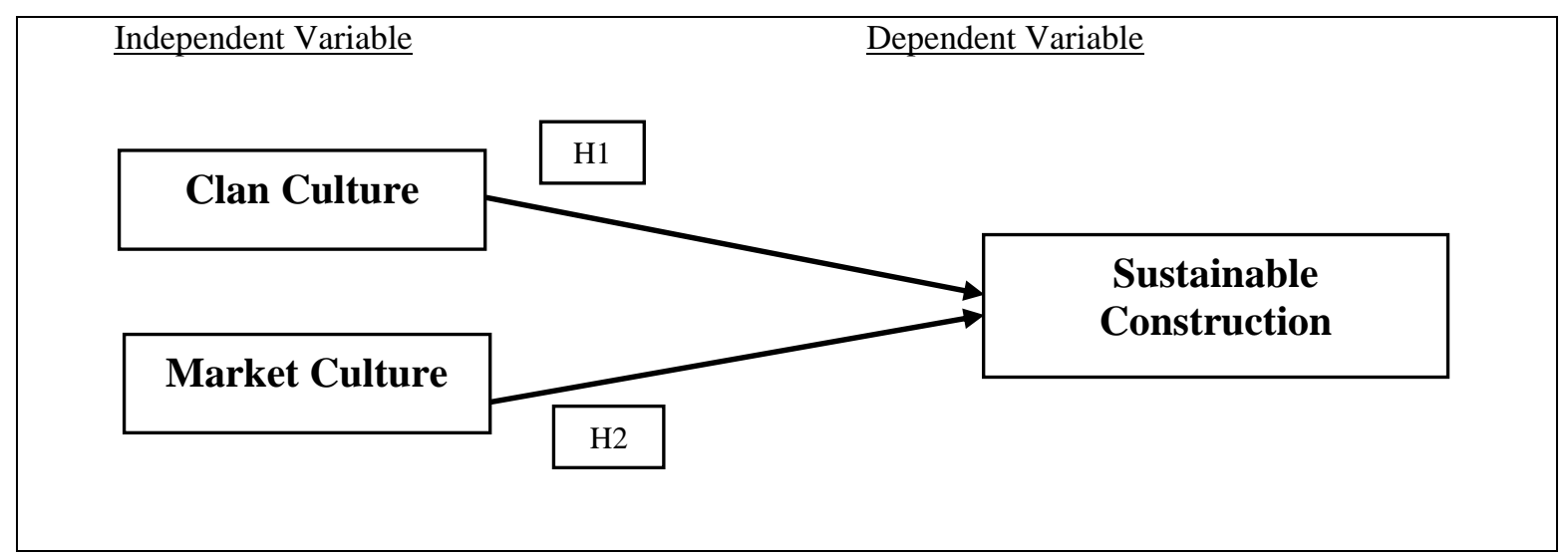

Fig.1. Conceptual framework

\section{Methodology}

The research approach is quantitative, which commonly adopted in social sciences (Sekaran, Robert \& Brain, 2001) as it uses objective testing, controlled, supports, or rejects hypothesis as well as reducing bias in data collection and analyses (Dowd, 2018). Therefore, all information will be assembled from construction industries in Johor, Malaysia by using a structured questionnaire for this research. To calculate and determine the sample size, GPower software was used to calculate the sample size in this research. According to the study of Monette et al. (2011), he stated that a structured questionnaire is one of the tools or ways to collect data and information. This questionnaire in survey research contains a question that was recorded by respondents from the construction industries. After that, the questionnaire was distributed to all respondents involved in this research. So, 107 sets of questionnaires were distributed to the respondent. The period of the data collection process took around 2 to 3 weeks to be completed.

\subsection{Instrument Design}

In this part, all variables were measured using the most appropriate survey mechanism. Five-point Likert scale to measure and from that, the respondent was being measured under categories of "Strongly disagree=1", "Disagree=2", "Agree=4", and "Strongly agree=5". After that, the information were analyzed using PLS-SEM Structural Equation Modelling (SEM). PLS-SEM is a second generation of multivariate data analysis method and it is commonly used in business inquiry (Statsoft, 2013). In addition, PLS-SEM also can be used in tackling or solving research problem by treating unobservable and hard to measure latent variables (Wong, 2013).

Table 1: Summarize the survey instrument in the questionnaires

\begin{tabular}{clcc}
\hline Section & Description & Variable & No. of item \\
\hline 1 & Demographic & - & 8 \\
2 & Clan Culture & IV's & 10 \\
3 & Market Culture & IV's & 10 \\
4 & Sustainable Construction & DV & 15 \\
\hline
\end{tabular}

\section{Results}

\subsection{Data Collection and Sample}

Response rate in this survey research reflects the number of individuals that were invited to participate in this study and the number of respondents who complete the questionnaire survey, and there is no specific response rate standard since they may differ across surveys (Subani et al. 2020; Samsudin et al., 2020). The summary of demographic scales of respondents for this research is as shown in Table 2 below. 


\begin{tabular}{|c|c|c|c|}
\hline Variable & Description & Frequency & Percentage \% \\
\hline \multirow[t]{5}{*}{ Position } & Contract Manager & 5 & $4.67 \%$ \\
\hline & Other & 58 & $54.21 \%$ \\
\hline & Project Manager & 11 & $10.28 \%$ \\
\hline & Safety Officer & 19 & $17.76 \%$ \\
\hline & Site Worker & 14 & $13.08 \%$ \\
\hline \multirow[t]{4}{*}{ Working experience } & $1-3$ years & 56 & $52.34 \%$ \\
\hline & 4-6 years & 40 & $37.38 \%$ \\
\hline & 7-9 years & 5 & $4.67 \%$ \\
\hline & $>10$ years & 6 & $5.61 \%$ \\
\hline \multirow[t]{2}{*}{ Gender } & Female & 17 & $15.89 \%$ \\
\hline & Male & 90 & $84.11 \%$ \\
\hline \multirow[t]{4}{*}{ Type of project } & Commercial Building & 31 & $28.97 \%$ \\
\hline & Educational Building & 14 & $13.08 \%$ \\
\hline & Other & 9 & $8.41 \%$ \\
\hline & Residential Building & 53 & $49.53 \%$ \\
\hline \multirow[t]{4}{*}{ Company existence } & $>10$ years & 89 & $83.18 \%$ \\
\hline & $1-3$ years & 4 & $3.74 \%$ \\
\hline & 4-6 years & 3 & $2.80 \%$ \\
\hline & $7-9$ years & 11 & $10.28 \%$ \\
\hline \multirow[t]{4}{*}{ Company prime location } & Across Malaysia & 63 & $58.88 \%$ \\
\hline & International markets & 9 & $8.41 \%$ \\
\hline & Local market areas & 21 & $19.63 \%$ \\
\hline & Within few States Regional & 14 & $13.08 \%$ \\
\hline \multirow[t]{4}{*}{ No. fulltime employee } & $>150$ & 90 & $84.11 \%$ \\
\hline & $0-50$ & 2 & $1.87 \%$ \\
\hline & $100-150$ & 9 & $8.41 \%$ \\
\hline & $50-100$ & 6 & $5.61 \%$ \\
\hline \multirow[t]{4}{*}{ Company ownership } & Government-owned Company & 4 & $3.74 \%$ \\
\hline & Local & 44 & $41.12 \%$ \\
\hline & National & 55 & $51.40 \%$ \\
\hline & Private & 4 & $3.74 \%$ \\
\hline Grand total & & 107 & 100.00 \\
\hline
\end{tabular}

\subsection{Measurement Model}

The first phase in the assessment of PLS-SEM analysis was conducted which is assessment of the measurement model (the outer loading). This is to evaluate the hypothesized model, the PLS-SEM method and statistical software SMARTPLS 3 (Ringle et al. 2015) were used. Figure 2 at below illustrates the measurement model of this research. 


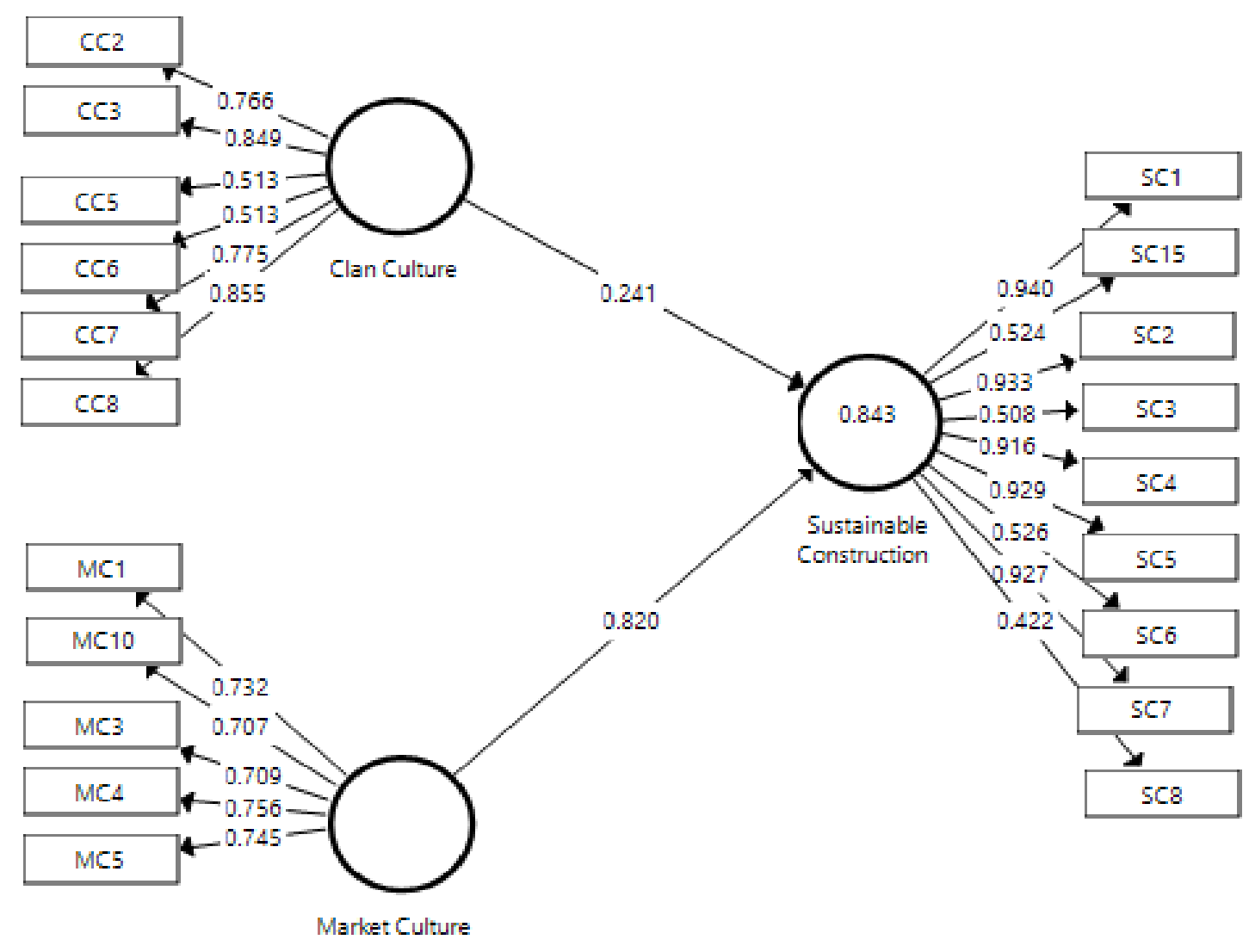

Fig.2. Measurement model

The researcher deleted 15 of the 35 items because the outer loadings were below the threshold. After that, for the whole model, 20 items were remained with the loading between 0.422 and 0.933 (Figure 2).

Table .3. Convergent Validity Analysis

\begin{tabular}{lcclcc}
\hline Construct & Item code & $\begin{array}{c}\text { Outer } \\
\text { Loading }\end{array}$ & AVE & CR & $\begin{array}{c}\text { Cronbach's } \\
\text { Alpha }\end{array}$ \\
\hline CC & CC2 & 0.766 & 0.528 & 0.866 & 0.814 \\
& CC3 & 0.849 & & & \\
CC5 & 0.513 & & & \\
& CC6 & 0.513 & & & \\
& CC7 & 0.775 & & 0.792 \\
MC & CC8 & 0.855 & & & \\
& MC1 & 0.732 & 0.533 & 0.851 & \\
& MC10 & 0.707 & & & \\
& MC3 & 0.709 & & & \\
SC & MC4 & 0.756 & & & \\
& MC5 & 0.745 & & & \\
& SC1 & 0.940 & 0.589 & 0.922 & \\
& SC15 & 0.524 & & & \\
& SC2 & 0.933 & & & \\
& SC3 & 0.508 & & &
\end{tabular}




$\begin{array}{ll}\text { SC4 } & 0.916 \\ \text { SC5 } & 0.929 \\ \text { SC6 } & 0.526 \\ \text { SC7 } & 0.927 \\ \text { SC8 } & 0.422\end{array}$

Note: $\mathrm{CC}=\mathrm{Clan}$ Culture, $\mathrm{MC}=$ Market Culture, $\mathrm{SC}=$ Sustainable Construction, $\mathrm{AVE}=$ Average

Variance Extracted, $\mathrm{CR}=$ Composite Reliability

Based on Table 3, the convergent validity shown the value of outer loading, Average Variance Extracted (AVE), Composite Reliability (CR), and Cronbach's Alpha. The outer loading value for each construct item is different but for Cronbach's Alpha, CR and AVE are the same for the same construct group item. Composite Reliability (CR) must be greater than 0.80, outer loading must be significant at not less than 0.05, the Average Variance Extracted (AVE) value must be greater than 0.50 for each construct, and 0.60 Cronbach alpha coefficients are considered appropriate (J. F. Hair, Ringle, \& Sarstedt, 2011).

Table 3 lists the Cronbach's Alpha of the variable used in this study which ranged from 0.792 to 0.089 and the CR scores of all constructs (Clan culture $=0.866$, Market culture $=0.851$, and Sustainable construction $=$ 0.922), all exceed the recommended criterion of 0.7 , demonstrating high internal consistency or the appropriateness of the scales used in this study (Avkiran, Zhu, Tripe, \& Walsh, 2017; Memon, Salleh, \& Baharom, 2016)

Table 4: Discriminant Validity Analysis: Fornell \& Larcker Criterion

\begin{tabular}{llll}
\hline Construct & CC & MC & SC \\
\hline CC & $\mathbf{0 . 7 2 6}$ & & \\
MC & 0.284 & $\mathbf{0 . 7 3 0}$ & \\
SC & 0.473 & 0.888 & $\mathbf{0 . 7 6 8}$ \\
\hline
\end{tabular}

In Table 4, Discriminant Validity indicates that an AVE score of 0.05 or higher is deemed acceptable. A comparison between square root of the AVE (appearing in bold) and the correlations of the latent constructs was also shown in Table 5, and it was evidence that AVE square roots are higher for all the construct along the diagonals than the corresponding off-diagonal coefficients in both columns and row, suggesting adequate discriminant validity in this research as seen in Table 4. Based on Table 4, the diagonal values (bolded) for CC (0.726), MC (0.730), and SC (0.768) is a square root of AVE.

Table 5: Summary of Hypotheses Testing

\begin{tabular}{|c|c|c|c|c|c|c|c|c|c|}
\hline \multirow[t]{2}{*}{ Hypothesis } & \multirow[t]{2}{*}{ Path } & \multirow[t]{2}{*}{$\begin{array}{l}\text { Std. } \\
\text { Beta }\end{array}$} & \multirow[t]{2}{*}{$\begin{array}{l}\text { Std. } \\
\text { Deviation }\end{array}$} & \multirow[t]{2}{*}{ T-Statistics } & \multirow[t]{2}{*}{ P-Values } & \multirow[t]{2}{*}{ Bias } & \multicolumn{2}{|c|}{$\begin{array}{c}\text { Confidence } \\
\text { interval bias } \\
\text { corrected }\end{array}$} & \multirow[t]{2}{*}{ Decision } \\
\hline & & & & & & & $5 \%$ & $95 \%$ & \\
\hline \multirow[t]{2}{*}{ H1 } & CC $->$ & 0.241 & 0.054 & 4.431 & 0.000 & -0.003 & 0.151 & 0.319 & Supported \\
\hline & $\mathrm{SC}$ & & & & & & & & \\
\hline \multirow[t]{2}{*}{$\mathrm{H} 2$} & MC -> & 0.820 & 0.037 & 22.469 & 0.000 & -0.005 & 0.764 & 0.873 & Supported \\
\hline & $\mathrm{SC}$ & & & & & & & & \\
\hline
\end{tabular}

Note: $\mathrm{p}<0.05$ (1-tailed) 
This part is to investigate the relationship that were hypothesized for this research after validating the goodness of the outer model. Table 5 shows the hypothesis testing. The result showed that Hypothesis 1, results indicated that there is a significant relationship between these variables, the relationship between clan culture and sustainable construction show that hypothesis1 was strongly supported with $(\beta=0.241, \mathrm{p}<0.00, \mathrm{~T}$-statistic $=4.431)$. Hypothesis 2 also show it supported the relationship which is show that there is significant relationship between market culture and sustainable construction with $(\beta=0.820, \mathrm{p}<0.00$, T-statistic $=22.469)$. Based on Table 4 above $\mathrm{H} 1$ and $\mathrm{H} 2$ are supported.

Table 6: Structural Models

\begin{tabular}{llllllllll}
\hline Hypothesis & Path & $\begin{array}{l}\text { Std. } \\
\text { Beta }\end{array}$ & $\begin{array}{l}\text { Std. } \\
\text { Deviation }\end{array}$ & T-statistic & $\begin{array}{l}\text { P- } \\
\text { value }\end{array}$ & Decision & $\mathbf{R}^{2}$ & $\mathbf{Q}^{2}$ & $\mathbf{f}^{2}$ \\
\hline H1 & CC -> & & & & & & & & \\
& SC & 0.241 & 0.054 & 4.431 & 0 & Supported & 0.843 & 0.562 & 0.339 \\
& & & & & & & & 3.932 \\
H2 & MC $>$ & & & & & & & & \\
\hline
\end{tabular}

$\mathrm{R} 2$ values of 0.75 is consider substantial, 0.05 as moderate, and 0.25 will consider as weak. R2 values 0.90 and above or higher are typically indicative of overfit. As a guideline, foe a given endogenous construct, Q2 values must be greater than zero to recommend the predictive precision of the structural model for the construct. Moreover, as a rule of thumb, Q2 values greater than 0.0 .25 and 0.50 represent the PLS-path model's small, medium, and high predictive significance. Then, Q2 effect sizes can be estimate or measure and interpreted in the same way as the f2 effect size.

\section{Discussion and Conclusion}

This research centered on clan culture and market culture as domains of organizational culture in Johor Malaysian construction industries in influencing sustainable construction. While ample research related to organizational culture and sustainable construction has been done, however, only a small portion of research related to organizational culture and sustainable construction in one single context has been done. The main objective of this study was to explore whether organizational culture matters regarding the relationships on sustainable construction. According to Hypothesis 1, the results produced indicated that there is a statistically significant association between clan culture and sustainable construction, suggesting that the more a construction firms leans towards the culture of clan, the easier the capacity of the firm to embrace sustainable construction in the implementation of the project. This outcome is aligned with past findings where the culture of adhocracy was outlined to represent a near connection with sustainability. Furthermore, hypothesis two (2) which stated that market culture would positively and significantly influence sustainable construction was found to be supported, as it was shown from the findings that market culture influences sustainable construction. The significance of these findings is that the more market culture a construction incorporate into its operation, the better its prospects of embracing sustainable construction would be. This result is in accordance with Green, et al. (2015) who reported that the market culture of business directly impacts sustainable environmental efficiency. Conclusively, it is concluded that organizational culture influences sustainable construction in Malaysian construction firms.

\section{Implications}

The research and studies on sustainable construction is not only helpful in academic world but also to the employer who requires more knowledge on organizational culture that related with sustainable construction in every construction industry. Furthermore, in term of improving the organizational culture on sustainable construction among construction industries, it is important for all construction companies to implement this culture into workplace. Thus, this research also gives a benefit to the academic world and the practitioners in the construction industry, especially for the industries that treasure humanity values and preserve the sustainable in every construction project. 


\section{Research Limitation}

The data obtained in this study only applicable for a worker in construction industries since it only gained a data from the worker in construction companies. It can be used only to measure the influence of organizational culture on sustainable construction and may not be used for other research that involving sustainable construction such as the food and beverages industry. Therefore, in order to enhance a wide knowledge, the future researcher can investigate and explore the other domains of organizational culture such as hierarchy culture or resolve to any internal or external factor that may influence on sustainable construction and empirically validate the proposed model in this research.

\section{REFERENCES}

Adeleke, A. Q., Nawi, M. N. M., \& Abd-Karim, S. B. (2020). Where are we? the level of risk management in Malaysian construction industries. Int. J Sup. Chain. Mgt Vol, 9(1), 527.

Abdul-Rahman, H., Berawi, M., Berawi, A., Mohamed, O., Othman, M. and Yahya, I. (2006). Delay mitigation in the Malaysian construction industry. J Constr Eng Manag. 132:125-133.

Abidin, N.Z. (2009). Sustainable construction in Malaysia - developers' awareness. Proc World Acad Sci Eng Technol. 41:807-814.

Agrawal, V. V., \& Bellos, I. (2017). The potential of servicizing as a green business model. Management Science, 63(5), 1545-1562.

Azman, N. A. S. M., \& Adeleke, A. Q. (2018). Effect of Time Overruns on Apartment Building among Kuantan Malaysian Construction Industries. Journal of Advanced Research in Applied Sciences and Engineering Technology, 10 (1), 41, 47.

Bamgbade, J. A., Nawi, M. N. M., Kamaruddeen, A. M., Adeleke, A. Q., \& Salimon, M. G. (2019). Building sustainability in the construction industry through firm capabilities, technology and business innovativeness: empirical evidence from Malaysia. International Journal of Construction Management, 1-16.

Bamgbade, J. A., Salimon, M. G., Adeleke, A. Q., \& Nasidi, Y. (2019). Contractor's technology acceptance for firm sustainability performance. KnE Social Sciences, 1084-1101.

Byrne, J. (2013). An examination of market orientated organisational culture (Doctoral dissertation, Institute of Technology Carlow).

Cameron, K. M., \& Quinn, R. E. (2006). Diagnosing and changing culture: based on the competing values framework of Indonesian company. 32, 223-262. https://doi.org/10.1016/j.aos.2006.03.009

Cameron, K. S., \& Quinn, R. E. (1999). An introduction to changing organizational culture. Diagnosing and changing organizational culture: Based on the competing values framework, 1-17

Cameron, K., \& Quinn, R. E. (2016). Organizational culture assessment instrument.

Chung, R. M., Adeleke, A. Q., \& Ajibike, W. A. (2020). CLIENT DELAY FACTORS AFFECTING BUILDING PROJECT PERFORMANCE AMONG KUANTAN MALAYSIAN CONSTRUCTION INDUSTRY: THROUGH PARTIAL LEAST SQUARE STRUCTURAL EQUATION MODELING. Economic Research, 4(1).

Desphandé, R., Moorman, C., \& Zaltman, G. (1993). Factors Affecting Trust in Market Research Relationship. Journal of Marketing, vol. 57, 81-101.

Dickinson, D. K., \& Neuman, S. B. (Eds.). (2007). Handbook of early literacy research (Vol. 2). Guilford Press.

Dowd, K. P., Szeklicki, R., Minetto, M. A., Murphy, M. H., Polito, A., Ghigo, E. and Tomczak, M. (2018). A systematic literature review of reviews on techniques for physical activity measurement in adults: a DEDIPAC study. International Journal of Behavioral Nutrition and Physical Activity, 15(1), 15

Du Plessis, C. (2002). Agenda 21 for sustainable construction in developing countries. (CSIR Report BOU E, 204).

Efferin, S., \& Hopper, T. (2007). Management control, culture and ethnicity in a Chinese

Giang, D.T. and Pheng, L.S. (2011). Role of construction in economic development: review of key concepts in the past 40 years. Habitat Int. 35:118-125. 
Goh, C.S. and Abdul-Rahman, H. (2013). The identification and management of major risks in the Malaysian construction industry. J Constr Dev Cries. 18:19-32.

Green, K.W., Toms, L.C. and Clark, J. (2015.) Impact of market orientation on environmental sustainability strategy. Manag Res Rev. 38:217-238

Hair, J. F., Sarstedt, M., Ringle, C. M., \& Mena, J. A. (2012). An assessment of the use of partial least squares structural equation modeling in marketing research. Journal of the academy of marketing science, 40(3), 414-433

Hamid, Z., Kamar, K., Ghani, M., Zain, M. and Rahim, A. (2011). The way forward of sustainable construction and green technology in Malaysia. In: Ariffin M, Ahnuar EM, Alwi S, Takim R, Bagdad M, editors. Management in Construction Researchers Association 9th Annual Conference and Meeting. Malaysia: Faculty of Architecture, Planning \& Surveying, UiTM Shah Alam; p. 155-166.

Ismayana, M. P., \& Adeleke, A. Q. (2020). The Influence of Organizational Culture on Construction Risk Management among Kuantan Malaysian Construction Industry: A Partial Least Square Structural Equation Modeling Approach. Social Science and Humanities Journal, 1693-1704.

Kanimoli, A., Adeleke, A. Q., \& Taiwo, T. T. (2020). ORGANIZATIONAL STRUCTURE INFLUENCE ON CONSTRUCTION WASTE MANAGEMENT AMONG PENANG MALAYSIAN CONSTRUCTION INDUSTRY: AN APPROACH VIA PARTIAL LEAST SQUARE STRUCTURAL EQUATION MODELING. Journal Homepage: https://www. jobmer. org, 4(1).

Kargas, A. D., \& Varoutas, D. (2015). On the relation between organizational culture and leadership: An empirical analysis. Cogent Business \& Management, 2(1), 1055953.

Khan, R. A., Liew, M. S., \& Ghazali, Z. B. (2014). Malaysian construction sector and Malaysia vision 2020: developed nation status. Procedia-social and behavioral sciences, 109, 507-513.

Liu, A.M., Fellows, R. and Tuuli, M.M. (2011). The role of corporate citizenship values in promoting corporate social performance: towards a conceptual model and a research agenda. Constr Manag Econ. 29:173183.

Mehr, S.Y. and Omran A. (2013). Examining the challenges affect on the effectiveness of materials management in the Malaysian construction industry. Int J Acad Res. 5:56-63.

Murray, P.E and Cotgrave, A.J. (2007). Sustainability literacy: the future paradigm for construction education? Sustain Lit. 25:7-23.

Obendhain, A. M., \& Johnson, W. C. (2004). Product and process innovation in service organizations: The influence of organizational culture in higher education institutions. Journal of Applied Management and Entrepreneurship, 9(3), 91.

Ofori, G. (1990). The construction industry: aspects of its economics and management. NUS Press

Ofori, G. (2001). Challenges facing construction industries in southern Africa. Keynote Address. In Regional Conference on Developing the Construction Industries of Southern Africa; Pretoria, South Africa, 23-25 April.

Qiang, L., Zhang, R., Tian-Quan, L., \& Li-Mei, Z. (2015). Piezoelectricity in K1- xNaxNbO3: First-principles calculation. Chinese Physics B, 24(5), 053101.

Qiang, M., Wen, Q., Jiang, H. and Yuan. S. (2015). Factors governing construction project delivery selection: a content analysis. Int J Project Manag. 33:1780-1794.

Omer, M. S., \& Adeleke, A. (2019). Systematic Critical Review of Risk Management in Malaysian Construction Companies. Journal of Humanities and Social Sciences Studies (JHSSS) Vol, 1.

Panda, S., Waris, M., Yusri, M., Adeleke, A. Q., \& Sarbani, W. M. N. (2020). Performance Appraisal System of Public Technical Universities of Malaysia-A Study. International Journal of Psychosocial Rehabilitation, 24(1).

Ringle, C. M., Wende, S., \& Becker, J.-M. (2015). SmartPLS 3. Boenningstedt: SmartPLS GmbH. 
Samsudin, N. S. A., Adeleke, A. Q., \& Ajibike, W. A. (2020). Effects of Contractors' Delay Factors on Building Project Performance Among Kuantan Malaysian Construction Industry. Social Science and Humanities Journal, 1705-1715.

Sekaran, U., \& Bougie, R. (2013). Research methods for business: A skill-building approach. [e-book].)

Shen, L.Y., Tam, V.W.Y., Tam, L. and Ji, Y.B. (2010). Project feasibility study: the key to successful implementation of sustainable and socially responsible construction management practice. J Cleaner Prod. 18:254-259.

StatSoft, I. (2013). Electronic statistics textbook. Tulsa, OK: StatSoft, 34.

Subani, N. A., Adeleke, A. Q., \& Bamgbade, J. A. (2020). The Role of Organizational Culture on Sustainable Construction among Malacca Malaysian Construction Industry: A Partial Least Square Approach. Social Science and Humanities Journal, 1681-1692.

Sugita, M. and Takahashi, T. (2015). Influence of corporate culture on environmental management performance: an empirical study of Japanese firms. Corp Soc Responsib Environ Manag. 22:182-192.

Taofeeq, D. M., Adeleke, A. Q., \& Ajibike, W. A. (2020). Human factors influencing contractors' risk attitudes: A case study of the Malaysian construction industry. Construction Economics and Building, 20(1), 96.

Tan, Y., Shen, L., Yao, H. (2011). Sustainable construction practice and contractors' competitiveness: a preliminary study. Habitat Int. 35:225-230.

Trong Tuan, L. (2012). Behind knowledge transfer. Manag Dec. 50:459-478.

Tuan, L. T. (2012). Behind knowledge transfer. Management Decision.

Ubius, U. and Alas, R. (2015). Organizational culture types as predictors of corporate social responsibility. Eng Econ. 61:90-99.

Wang, C., \& Abdul-Rahman, H. (2010). Decoding organizational culture: A study of Malaysian construction firms. African Journal of Business Management, 4(10), 1985-1989.

Wang, N. (2014). The role of the construction industry in China's sustainable urban development. Habitat Int. 44:442-450.

Wong, K. K. K. (2013). Partial least squares structural equation modeling (PLS-SEM) techniques using SmartPLS. Marketing Bulletin, 24(1), 1-32 